\section{Isolation of Progesterone from Human Pregnant Myometrium}

ZANDER 1 has reported that "with the methods presently availablo it has never been found possible to demonstrate non-labelled progesterone or either of the $\Delta 4$-3-ketopregnene-ol-one isomers in tho target tissues, uterino muscle and mucosa". With the aid of gas-liquid phase chromatography wo have isolated non-labelled progesterono from the human prognant myomotrium and this report deals with the method used and the concentrations of the steroid found.

The technique for qualitative and quantitative isolation of progesterone, using gas-liquid phase chromatography, was first perfected in placental tissue. The details of this procedure have been described elsewhere ${ }^{2}$. Essentially it consists of 5 per cent sodium hydroxide digestion, extraction of crude lipids with ether, partial purification of cholesterol on silicic acid column and final separation of progesterone on gas chromatogram using 2 por cent ' $S E$ 30' (General Electric) as liquid phase.

The qualitative identification of progesterone was confirmed by the following procedure:

(1) The retention times on the gas column chromatogram for the other closely related steroids were obtained and none of the steroids tested had the same retention time as progesterone.

(2) The peak from the gas eolumn which displayed the same retention time as crystalline progosterone was collected and subjected to ultra-violet absorption analysis. Both the tissue extract and the standard exhibited maxima at $240 \mathrm{~m} \mu$ were suggestive of unsaturated, $\lambda-\beta$ ketonic di-substitution.

(3) The 'progesterone' peak from analysis of the tissue on the gas column was also subjected to bioassay by a modification of the McGinty procedure ${ }^{3}$ and gave a $4+$ response for progesterone in the endometrium of rabbits. (We thank Dr. Arthur L. Haskins, of the University of Maryland, Baltimore, for the bioassays and ultra-violet absorption spectra.)

After ostablishing with placental tissue the technique for the isolation of progesterone by gas column chromatography, human myometrium was analysed using the same procedure. In order to obtain a peak suitable for accurate measurement, however, the myometrial tissue samples had to be in the range of 40-45 $\mathrm{g}$ each, therefore confining the studies to women having cæsarean hysterectomy.

Table 1. Myometrial Progesterone

\begin{tabular}{cccc} 
No. & History & \multicolumn{2}{c}{$\begin{array}{c}\mu \text { progesterone/g wet } \\
\text { weight myometrial tissue }\end{array}$} \\
& & $P$ & $A P$ \\
1 & Pooled myometrial biopsies & 0.63 & $0 \cdot 31$ \\
2 & Mrs. A. R.-12 weeks & $0 \cdot 15$ & $0 \cdot 08$ \\
3 & Mrs. R. C.-38 weeks & 0.16 & $0 \cdot 10$ \\
4 & Mrs. V.T.--39 weeks & 0.11 & 0.12
\end{tabular}

$P$, myometrium overlying the placental site; $A P$, myometrium directly opposite to placental attachment.

With this procedure, $0 \cdot 08-0 \cdot 63 \mu \mathrm{g}$ of progesterone per gram of wet weight of tissue was found (Table 1). Bioassay and ultra-violet absorption spectra were carried out as before. The bioassay gave a 1 to $3+$ progestin response, and the ultra-violet absorption was in the vicinity of $240 \mathrm{~m} \mu$ due to very low concentrations. In addition, the final extract was run in threo different liquid phases, 2 per cent 949,1 per cent 149-244, 2 per cent ' $X F-1125$ ' (General Electric), and the 'progesterone' peak from the unknown sample had in each of these instances the same retention time as the standard progesterone.
Finally, to eliminate the possibility that these small amounts represent measurements of plasma progesterone retained in the tissues despito the careful blotting of the cut pieces in order to remove blood, hæmoglobin determinations were carried out and the maximum plasma content estimated as $8.5 \mathrm{ml} / 100$ g wet weight. (We thank Mr. Daniel Kooyman for the analysis of tissue plasma content.) Fven assuming 15 $\mu \mathrm{g}$ of progesterone per $100 \mathrm{ml}$. of plasma, the determined tissue-levels exceed any reasonable plasma concentration by several-fold $(0.012 \mu \mathrm{g}$ calculated from plasma sources versus the $0.08-0.6 \mu \mathrm{g}$ found).

$$
\begin{aligned}
& \text { 1). Kumar } \\
& \text { J. A. Goonno } \\
& \text { A. C. Barnes }
\end{aligned}
$$

Department of Gynecology and Obstetrics, Johns Hopkins University

School of Medicine and Hospital, Baltimore.

' Zander, J., Progesterone: Brook Lodge Symp., 83 (Brook Lodge Press, Augusta, Michigan, 1960).

${ }^{2}$ Kumar, D., Johnson, J. W. C., Turner, D. A., and Barnes, A. C., Anal. Biochem. (in the pross).

${ }^{3}$ MeGinty, D. A., Anderson, L. P., and McCullough, N. B., Endocrinol., 24, 829 (1939).

\section{Development of $\mathrm{H}$ Activity by Human Blood-Group B Substance treated with Coffee Bean $\alpha$-Galactosidase}

THE appearance of $H$ specificity in the nondiffusible products remaining after the enzymatic destruction of $A$ and $B$ blood-group specificities has been observed with enzyme preparations from sevoral different micro-organisms. Iseki and Masaki ${ }^{1}$ first reported that an A-decomposing enzyme from the bacterium Clostridium tertium destroyod the A serological activity of human saliva and hog A preparations and gave products which had $\mathrm{H}$ sorological activity not shown by the A preparations before enzyme treatment. Enzyme proparations from the protozoan Trichomonas foetus similarly decompose A substance of human ovarian eyst and saliva origin with the disappearance of A specificity and the appearance of $\mathrm{H}$ specificity ${ }^{2}$. Extracts from T. foetus also contain a different enzyme which acts on human B substance with the destruction of $B$ serological properties and the appearance of $\mathrm{H}$ specificity $\mathrm{s}^{2,3}$, and bacterial enzymes from Bacillus cereus ${ }^{4}$ and Clostridium maebash $i^{5}$ induce the same specificity changes in B substance.

The B-decomposing enzymes from these microorganisms have not been obtained in a sufficiently puro state for their specificity to be determined unequivocally by their action on substrates of known structure. On the basis of enzymatic hydrolysis and inhibition experiments, however, a D-galactosidase specificity was inforred. Loss of B activity of human ovarian cyst B substance by the action of the partially purified enzyme from $T$. foetus was accompanied by the release of reducing sugars (equivalent to 5 per cent of glucose) which consisted of a major galactose component with only traces of fucose and $N$-acetylhexosamine ${ }^{3}$; and the enzyme from $\mathrm{Cl}$. maebashi, when allowed to act on B substance from human stomach linings, liberated about 8 por cent of tho original galactose and no other sugar ${ }^{6}$. The action of the $T$. foetus enzyme on B substance was inhibited by D-galactose and not by any of the other sugars in the blood-group substances? ${ }^{7}$, and when this inhibition occurred there was no development of $H$ specific activity ${ }^{2,3}$. These results therefore suggested that the 